\title{
ARTICLE
}

\section{Lex sportiva as the contractual governing law}

\author{
Leonardo V. P. de Oliveira ${ }^{1}$
}

Published online: 10 November 2017

(c) The Author(s) 2017. This article is an open access publication

\begin{abstract}
Contracts involving sports matters, such as the participation of an athlete in an international sports competition, would normally have a clause submitting disputes to arbitration under the rules of the Court of Arbitration for Sports. As a result, in international sports disputes, the subject matter of disputes has been predominantly decided by a private tribunal. In making such decisions, the Court of Arbitration of Sports has been interpreting and applying the rules established by sports governing bodies. Consequently, in its 30 years of existence, the Court of Arbitration for Sports has produced a rich jurisprudence regarding sports disputes. Such body of case law, combined with the rules of the sports governing bodies, has created what today is called a lex sportiva. Hence, this paper aims at analysing the concept of the lex sportiva to trace a parallel to its closest source of transnational law, the lex mercatoria. From that, following the principle of party autonomy, it will be argued if lex sportiva is already the governing law in some sports-related contracts or if it is desirable, whether lex sportiva can become the governing law to a contract in the same manner that today lex mercatoria can be the parties' choice of law in a contract.
\end{abstract}

Keywords Lex sportiva P Party autonomy · Applicable law to contracts

L. V. P. de Oliveira would like to thank Mr. Tom Serby and Dr. Johanna Hoekstra for the comments on the early draft of this article. All mistakes of interpretation and translations are the author's own.

Leonardo V. P. de Oliveira

leonardo.oliveira@rhul.ac.uk

1 Lecturer in Law, School of Law, Royal Holloway, University of London, Egham Hill, Egham TW200EX, UK

\section{Introduction}

Establishing a governing law to a contract facilitates the performance of the contract and it provides a guide on how to solve disputes arising out of such contract. The ordinary option would be use of a domestic law to regulate the rules of a contract. However, the development of contract law, especially in international transactions, allows the employment of a system of laws with a transnational character to be the lex contractus. ${ }^{1}$ As a result, different approaches are being used as the applicable law, such as the lex mercatoria, general principles of law, soft law and general principles of public international law. ${ }^{2}$ The mentioned examples do not represent an exhaustive list, being part of a bigger group of global laws which are not created by states. ${ }^{3}$ In this global cluster, other transnational laws developed from different areas of law such as in sports law.

It is hard to neglect that there is a body of law created by reiterated decisions regarding sports disputes issued by the Court of Arbitration of Sports (CAS). ${ }^{4}$ Such jurisprudence has been called lex sportiva, which has also been recognised as a source of transnational law. ${ }^{5}$ But that is not the only approach regarding lex sportiva. When deciding, the CAS arbitral panel must apply the rules of law chosen by the parties or the applicable regulations. ${ }^{6}$ The chosen law

\footnotetext{
${ }^{1}$ Goode et al. (2015), p. 23.

2 Cordeiro-Moss (2014), pp. 31-32.

3 Teubner (1997), p. 2.

${ }^{4}$ Blackshaw (2009), p. 179 and Nafziger (2004), p. 3.

5 Duval (2013), p. 825.

${ }^{6}$ See rules 45 and 58 of the CAS Code of Sports-related Arbitration addressed below in Sect. 6 .
} 
or the applicable regulations are normally the rules established by sports governing bodies (SGB). ${ }^{7}$ Hence, a broader view is that lex sportiva is not solely made of the CAS jurisprudence but the rules and regulations imposed by the SGBs and their interpretation by $\mathrm{CAS}^{8}$ As lex sportiva is a framework of rules either developed by the SGBs or by decisions of an international Court of Sports, having a similar nature to other sources of transnational law, one must argue if it is already accepted that lex sportiva is the governing law to sports-related contracts or if it can be the governing law to a contract? This article tries to answer such question by arguing that if other sources of transnational law, such as lex mercatoria, can be employed as the governing law to a contract there should be no obstacle for the same to be done to lex sportiva. Nevertheless, despite the apparent permissibility, the study will also examine the practicality and functionality of using lex sportiva as the contract's governing law. To reach such conclusion, the first point to be addressed will be the nature of a contract involving sports activities followed by the analysis of party autonomy and its instruments. In sequence, an assessment of lex sportiva and a parallel to lex mercatoria will be made. By describing what is the lex sportiva and also the concept and application of lex mercatoria, the article will set the scene to understand how such transnational sources work to finally verify if the application of lex sportiva as the lex contractus is viable or it is a mere theoretical debate.

\section{Contracts involving sports activities}

As some aspects of sports law derive from other fields of law such as contract, tort and competition law, the idea that sports law has developed into its own field does not find a common ground in the sports law literature. ${ }^{9}$ According to Davis, there are three perspectives. ${ }^{10}$ The first approach is that there is no such thing as sports law because it is an amalgamation of other areas of law applied to sports activities. That is, sports law has no unique value to make it an independent field of law. For that reason, 'no separately identifiable body of law exists that can be characterized as sports law'. ${ }^{11}$ The second view is that there is room for it to develop into a field of law. There are specific issues related to sports which require a different approach from other areas of law. In its application, the general aspect of the

\footnotetext{
7 See IAAF v. CADA \& Witteveen, Arbitration CAS 2002/A/417, award of 12 May 2003 paragraphs 80-83.

${ }^{8}$ Simon (2014), pp. 131-134.

9 Siekmann (2011), p. 2.

${ }^{10}$ Davis (2001), pp. 212-216.

11 Ibid., p. 212.
}

law creates a new method to its application in the sports context. The third perspective is that sports law is an independent field of law that can be found in case law and in specific legislation about sports. In this last category, sports law will have different origins. If the object of sports is a piece of legislation, the debate here will focus on a domestic approach to sports, that is, the regulation made by a state to its sports activities. It is easy to find in several legal systems a statute about sports. In France, there is a Sports Code establishing that sports activities are of general interest. ${ }^{12}$ In Brazil, the Constitution established a Court of Sports to deal with sport-related issues and it also determined that the judiciary can only address sports claims once a decision from the Court of Sports has been qualified as res judicata in the instances of the Court of Sports. ${ }^{13}$ Common law countries do not fall far from the Civil Law examples: the United States of America has an Amateur Sports Act of 1978 while New Zealand enacted in 2002 a Sport and Recreation Act. ${ }^{14}$ Nevertheless, if the legitimacy of the new area of law is based on case law, a distinction must be made. If the ruling emanates from a State Court, it is just affirming the domestic legislation but if it derives from CAS decisions, it has a private and a transnational nature.

It is obvious that sports law does not stand on its own without being influenced by other fields of law. Issues related to sports disputes have roots in principles and rules from different areas of law. For instance, a sports activity might originate from a contract, therefore, contract law will be applicable; if there is a civil harm created by a sports

\footnotetext{
${ }^{12}$ Law n ${ }^{\circ} 2017-86$ of 27 January 2017, Article L-100-1 of the code declares: 'Physical and sports activities constitute an important element of education, culture, integration, and social life. They contribute particularly to the fight against school failure and the reduction of social and cultural inequalities, as well as to health. The promotion and development of physical and sporting activities for all, particularly for disabled persons, are of general interest.'

13 Article 217 of the 1988 Constitution of the Federal Republic of Brazil express: 'It is the duty of the State to foster the practice of formal and informal sports, as a right of each individual, with due regard for: I-the autonomy of the directing sports entities and associations, as to their organisation and operation; II-the allocation of public funds with a view to promoting, on a priority basis, educational sports, and in specific cases, high performance sports; III-differentiated treatment for professional and non-professional sports; IV - the protection and fostering of sports created in the country. Paragraph 1. The Judicial Power shall only accept legal actions related to sports discipline and competitions after the instances of the sports courts, as regulated by law, have been exhausted. Paragraph 2 . The sports courts shall render final judgement within 60 days, at the most, counted from the date of the filing of the action. Paragraph 3. The Government shall encourage leisure, as a form of social promotion.'

${ }^{14}$ Article 3 of the New Zealand Sport and Recreation Act 2002 states that ' $[\mathrm{t}] \mathrm{he}$ purpose of this Act is to promote, encourage, and support physical recreation and sport in New Zealand by establishing an agency called Sport and Recreation New Zealand'.
} 
event, tort law will be applicable; and if there is an issue regarding the right to use an athlete's image, intellectual property law might have to be employed. Be that as it may, the use of several aspects of law within one specific subject is a pathway for the creation of a new field of law. Until commerce was done electronically, no one thought that there should be a field of law related to e-commerce-after all, e-commerce is just commerce through electronic means. Nevertheless, due to its intricacies, legislation regarding the matter was enacted at regional and international levels, ${ }^{15}$ giving legitimacy to e-commerce law. It is hard to imagine that new areas of law would emerge in isolation, without any impact from the well-established fields of law. Therefore, sports law is a body of law that 'straddles the boundaries between many well-known branches of our law, but has at its centre an unusual form of international constitutional principle prescribing the limited autonomy of non-governmental decision making bodies in sport'. ${ }^{16}$

But within the area of sport, what is the role of contracts? The answer is not straight forward because different contracts touch on a variety of sports aspects. This format generates a contractual web which, in the case of professional athletes, is dense. ${ }^{17}$ The determining factor should be to identify who are the parties to the contract. When a party can be recognised, it can be easier to determine the nature of the contract. For instance, a contract between professional athletes and a sports club will be an employment contract. ${ }^{18}$ The employment status also applies to professional athletes and sports organisations. In the Fédération Internationale de Football Association's (FIFA) Professional Football Player Contract Minimum Requirements, it states in number 3.2 that ' $[\mathrm{t}]$ he agreement regulates an employment contract for a professional player'. ${ }^{19}$ The employee scenario works in collective or individual sports when such person represents a sports club. However, it is not in every sport modality that athletes will be part of a sports institution. For instance, tennis players tend to work almost as self-employed, and when they join a competition they are not representing an entity but

\footnotetext{
15 See for instance the UNCITRAL Model Law on Electronic Commerce (1996), the United Nations Convention on the Use of Electronic Communications in International Contracts (New York, 2005) and the Directive 2000/31/EC of the European Parliament and of the Council of 8 June 2000 on certain legal aspects of information society services, in particular electronic commerce, in the Internal Market ('Directive on electronic commerce') [2000] OJL 178.

16 Beloff et al. (2012), pp. 6-7.

17 Anderson (2010), p. 258.

18 Gardiner et al. (2006), p. 397.

19 Circular number 1171 of 24 November 2008. In http://www.fifa. com/mm/document/affederation/administration/97/29/01/circularno. 1171-professionalfootballplayercontractminimumrequirements.pdf (accessed on 22 February 2017).
}

themselves. $^{20}$ Thus, they have an individual contract to participate in the competition that they are adhering to.

Yet, this is not the only type of contract involving sports activities. An individual might also have a contract of membership with the sports club or the sports association in which he/she is a member. Once the individual joins the sports institution, the person is bound by the rules of the entity. A similar situation applies to sports bodies. Once a sports club or a sports association joins a specific sports organisation they are contractually bound by the rules of such institution, relying on the organisation's regulations to make complaints and also use adjudicatory systems of dispute resolution. Additionally, there are several other commercial contracts deriving from a sporting activity that do not aim to control the game but to commercially benefit from profits made out of sports activities. Such contracts vary from sponsorships, right of image, broadcasting rights, agency, etc. In this case, it is easy to see these transactions playing a major role in big sports events such as the Olympic Games and the FIFA World Cup.

Despite the different types of contractual frameworks applied to sports activities, sports contracts are subject to the regulation of general contract law, and as a result, when a dispute arising out of the agreement is triggered, the adjudicators will need a governing law to decide the impasse. Before assessing whether lex sportiva can be such a governing law to the contracts mentioned above, we must examine what party autonomy entails.

\section{Contracts and party autonomy}

Parties are free to contract as long as their contract does not violate a mandatory rule of law or the public policy of the jurisdiction in which the contract is being performed or enforced. ${ }^{21}$ From this freedom of contract derives the parties' right to select the law that will rule their contract. This party autonomy, which is a conflict of rule for contracts, ${ }^{22}$ dates back to the $1500 \mathrm{~s}^{23}$ and it is a fundamental aspect of contract law, especially in international

\footnotetext{
${ }^{20}$ Beloff et al. (2012), p. 38.

${ }^{21}$ Such view has been recognised by old English case law in Printing and Numerical Registering Company v. Sampson (1875) 19 Eq 462 , per Sir G. Jessel: 'It must not be forgotten that you are not to extend arbitrarily those rules which say that a given contract is void as being against public policy, because if there is one thing which more than another public policy requires it is that men of full age and competent understanding shall have the utmost liberty of contracting, and that their contracts when entered into freely and voluntarily shall be held sacred and shall be enforced by Courts of justice.'

22 Cordeiro-Moss (2014), p. 135.

23 Zhang (2006), p. 516.
} 
contracts. $^{24}$ It is imperative for parties to know which law governs their contract to understand the set of rules governing their obligations and how to perform the contract.

In the European Union, the Rome I regulation ${ }^{25}$ provides for the principle of party autonomy in its Article 3 as it states that '[a] contract shall be governed by the law chosen by the parties'. The article also declares that the law should be the law of a country as there are no provisions for rules of law or another non-national system of law. ${ }^{26}$ English Courts interpreting the Convention have excluded the application of a law that is not a domestic law of a European Union Member. ${ }^{27}$ Switzerland has a similar approach but it does not specify that the law has to be of a country. Article 116(1) of its Private International Law Act (PILA) express that ' $[\mathrm{t}]$ he contract shall be governed by the law chosen by the parties'. ${ }^{28}$ The fact that it does not say that the law has to be of a country does not necessarily

\footnotetext{
${ }^{24}$ See The Hague Principles on Choice of Law in International Commercial Contracts 2015: 'I.3 Party autonomy, which refers to the power of parties to a contract to choose the law that governs that contract, enhances certainty and predictability within the parties' primary contractual arrangement and recognises that parties to a contract may be in the best position to determine which set of legal principles is most suitable for their transaction. Many states have reached this conclusion, and as a result, giving effect to party autonomy is the predominant view today. However, this concept is not yet applied everywhere.'

25 Regulation (EC) No 593/2008 of the European Parliament and of the Council of 17 June 2008 on the law applicable to contractual obligations (Rome I) [2008] OJ L 177.

${ }^{26}$ Article 3 (3) addresses the question about the law of the country stating that 'Where all other elements relevant to the situation at the time of the choice are located in a country other than the country whose law has been chosen, the choice of the parties shall not prejudice the application of provisions of the law of that other country which cannot be derogated from by agreement.'

${ }^{27}$ In Shamil Bank of Bahrain EC v. Beximco Pharmaceuticals Ltd and others [2004] 1 W.L.R. 1784, Lord Justice Porter declared: 'The wording of Article 1(1) of the Rome Convention ("The rules of this Convention shall apply to contractual obligations in any situation involving a choice between the laws of different countries") is not on the face of it applicable to a choice between the law of a country and a non-national system of law, such as the lex mercatoria, or "general principles of law", or as in this case, the law of Sharia. Nevertheless, that wording, taken with Article 3(1) ("A contract shall be governed by the law chosen by the parties") and the reference to choice of a "foreign law" in Article 3(3), makes it clear that the Convention as a whole only contemplates and sanctions the choice of the law of a country.' The case concerned the predecessor of the Rome I Regulation but the wording of the articles has not changed in this regard and therefore the Convention should still be applicable.

28 The full text of the article provides: 'Art. 116. (1) The contract shall be governed by the law chosen by the parties. (2) The choice of law must express or clearly evident from the terms of the contract or the circumstances. In all other respects it shall be governed by the law chosen. (3) The choice of law may be made or modified at any time. If made or modified following the conclusion of the contract, it shall be retroactive to the time the contract was concluded. The rights of third parties shall take precedence.'
}

mean that it accepts transnational rules to be the governing law. ${ }^{29}$ Conversely, when it comes to arbitration, under Article $187(1)$ of the PILA, ${ }^{30}$ the provision regarding the applicable law refers to rules of law and not a national law.

A more precise approach can be identified in Paraguay. Its International Private Law $\mathrm{Act}^{31}$ provides for the principle of party autonomy in the same manner as the Swiss statute, ${ }^{32}$ but it goes further by stating in Article 5 that '[i]n this law, a reference to law includes rules of law that are generally accepted on a non-state origin, as a neutral and balanced set of rules'. The Paraguayan example clearly allows transnational laws to be selected as the governing law for contracts. The approach adopted in Paraguay reflects the international trend to accept transnational systems as the governing law. In 2015, the Hague Convention on International Private Law approved its Principles on Choice of Law in International Commercial Contracts. ${ }^{33}$ Article 3 of the principles provides that parties in a contract may choose 'rules of law that are generally accepted on an international, supranational or regional level as a neutral and balanced set of rules, unless the law of the forum provides otherwise'. The principles are a soft law; however, they can be highly influential not only for future

\footnotetext{
${ }^{29}$ See Graziano (2009), p. 426, who argues that while academic opinion in relation to the application of non-national rules is divided, the Swiss Courts have already decided that 'autonomous rules of private organisations do not have the legal status of legal rules, even if they are very detailed.'

30 According to the French version of the Private International Law Act 1987, Article 187(1) refers to the rules of law (règles de droit) and following the drafting history of the Act, such view should prevail, see Berger and Kellerhals (2015), p. 486/487. However, in the English version, the wording of the article is: 'Applicable law 1 The arbitral tribunal shall rule according to the law chosen by the parties or, in the absence of such choice, according to the law with which the action is most closely connected. 2 The parties may authorize the arbitral tribunal to rule according to equity.

${ }^{31}$ Ley N$^{\circ} 5393$ del 14 de enero de 2015: Sobre el derecho aplicable a los contratos internacionales.

32 The Act determines in Article 4: '(1) A contract is governed by the law chosen by the parties. (2) The parties may choose: a) The law applicable to the whole contract or to only part of it; and b) Different laws for different parts of the contract, in the measure that these are clearly distinguished. (3) The choice may be made or modified at any time. A choice or modification made after the contract has been concluded shall not prejudice its formal validity or the rights of third parties. (4) No connection is required between the law chosen and the parties or their transaction.'

33 According to I.8 of the Principles, the instrument's nature is of 'a non-binding set of principles, which the Hague Conference encourages States to incorporate into their domestic choice of law regimes in a manner appropriate for the circumstances of each State. In this way, the principles can guide the reform of domestic law on choice of law and operate alongside existing instruments on the subject (see Rome I Regulation and Mexico City Convention both of which embrace and apply the concept of party autonomy).'
} 
arbitration but also to legislators that might rely on it to draft statutes. $^{34}$

The scenario finds more freedom when it comes to arbitration. It is common for an Arbitration Act to permit the parties to select a non-national system of law as the applicable law to the dispute. In Spain, the Arbitration Act allows the arbitrators to decide according to "such rules of law as are chosen by the parties' and should also take usages into account. ${ }^{35}$ The French Code of Civil Procedure, in Article 1511 adopts the same position. ${ }^{36}$ The English Arbitration Act 1996 permits the parties to choose a nonnational law to be applicable to the substance of the dispute. $^{37}$ In interpreting the Act, Justice David Richards described that the statutory view

allows the parties the freedom to apply a set of rules or principles which do not in themselves constitute a legal system. Such a choice may thus include a nonnational set of legal principles (such as the 1994 UNIDROIT Principles of International Commercial Contracts) or, more broadly, general principles of commercial law or the lex mercatoria. ${ }^{38}$

As can be seen, party autonomy provides the option of choosing a state law as well as a transnational law to govern the contract. Not all legal systems will be so permissible to accept a non-national legal system to be applicable; conversely, it is plausible that a transnational law could be employed to solve a dispute through arbitration.

\footnotetext{
34 Petsche (2014), p. 497.

35 Article 34 of the Arbitration Act: '(1) The arbitrators shall decide in equity only if the parties have expressly authorized them to do so. (2) Subject to the previous paragraph, where the arbitration is international, the arbitrators shall decide the dispute in accordance with such rules of law as are chosen by the parties. Any designation of the law or legal system of a given State shall be construed, unless otherwise stated, as referring to the substantive law of that State and not to its conflict of laws rules. Failing any designation by the parties, the arbitrators shall apply the law that they consider appropriate. (3) In all cases, the arbitrators shall decide in accordance with the terms of the contract and shall take into account the applicable usages.'

36 Article 1511: 'The arbitral tribunal shall decide the dispute in accordance with the rules of law chosen by the parties or, where no such choice has been made, in accordance with the rules of law it considers appropriate. In either case, the arbitral tribunal shall take trade usages into account.'

${ }^{37}$ Section 46 of the Act states: 'Rules applicable to substance of dispute. (1) The arbitral tribunal shall decide the dispute - (a) in accordance with the law chosen by the parties as applicable to the substance of the dispute, or (b) if the parties so agree, in accordance with such other considerations as are agreed by them or determined by the tribunal.'

38 Sayyed Mohammed Musawi v. R.E. International (UK) Ltd and Others [2007] EWHC 2981 (Ch), paragraph 22.
}

\section{The lex sportiva}

For some time, the debate over the existence of a transnational sports law has been the subject of academic scrutiny, ${ }^{39}$ yet, as in most academic debates, there is no unanimously accepted concept. ${ }^{40}$ Likewise, the term lex sportiva in itself is controversial. ${ }^{41}$ It is a made-up term as the word sportiva is not found in Latin. ${ }^{42}$ It is an adaptation from a similar term which is also a source of transnational law, that is, the lex mercatoria.

The discussions regarding lex sportiva focus on the possible existence of a transnational law dedicated to legal issues involving sports. Being sports law-an autonomous area of law-what is lex sportiva and how does it relate to sports law? The first view, a narrow perspective, is that lex sportiva is the amalgamation of reiterated decisions made by CAS. ${ }^{43}$ Such decisions do not follow the principle of stare decisis as there is no such provision in the CAS rules determining so. Therefore, as the last instance in the established hierarchy made by sports organisations, CAS produced a body of law detached from a legal system, grounded on international sports rules, which finds legitimacy by the fact that an arbitral tribunal has issued a decision based on it and such decision has been complied with. Another opinion, the broader perspective, sees lex sportiva beyond the CAS jurisprudence and also incorporating 'rules and regulations drawn up by the international sporting organisations'. ${ }^{44}$ CAS does not work alone, and when deciding disputes, it is applying the regulations drafted by the sports bodies in which athletes participate. Hence, it is reasonable to consider that although CAS has made new principles regarding sports law, the decisions based on the organisations' rules contribute to the jurisprudence, that is, the lex sportiva. Additionally, athletes can also try to contribute to the formation and changes in such regulations, giving (at least apparently) more legitimacy to stakeholders upon the creation of lex sportiva. Therefore, the two perspectives complement each other, meaning that lex sportiva is made of CAS decisions which were issued by interpreting SGB regulations.

However, the concept is not so straight forward because it has been argued that the definition of lex sportiva in a sense is misused and what we have is a distinction between international sports law and global sports law. ${ }^{45}$ Such view asserts that

\footnotetext{
39 See Nafziger (2004); Blackshaw (2009), Chapter 15; Kolev (2008); Casini (2011); Duval (2013); Siekmann (2011); Blackshaw (2011); Latty (2007); Parrish (2012); Wolf (2014); and Panagiotopoulos (2011).

${ }^{40}$ See for instance Foster (2003).

41 According to McLaren (2001), p. 381 footnote 11, the term lex sportiva was coined by 'the Acting General Secretary of CAS Matthieu Reeb at the time of the publishing of the first digest of CAS decisions stretching over the period 1983-1998.'

42 Siekmann (2011), p. 153.

43 Nafziger (2004), p. 3.

${ }^{44}$ Duval (2013), p. 827

${ }^{45}$ Foster (2003), p. 2.
} 
international sports law is the 'principles of international law applicable to sport', ${ }^{46}$ while global sports law was 'defined as a transnational autonomous legal order created by the private global institutions that govern international sport' ${ }^{47}$ Hence, to put both ideas together as lex sportiva would be wrong: international sports law is based on rules enacted by states to its international relations and they can be applied by courts; while global sports law is a self-sufficient system disconnected from any domestic regulation, ${ }^{48}$ giving sports organisations immunity from any national law. Such perspective has its merits and it finds similar criticism in other areas of law. ${ }^{49}$ The difference perhaps is that aspects of this autonomous legal order are not completely detached from a legal system as they are materialised through arbitration. It is hard to envisage an award that is free from challenge in a domestic court. ${ }^{50}$ Even awards issued under the Convention on the Settlement of Investment Disputes Between States and Nationals of Other States, which are, according to its Article 53(1), 'binding on the parties and shall not be subject to any appeal or to any other remedy except those provided for in this Convention', will be the subject of national rules when being executed by a court where enforcement is being sought. ${ }^{51}$ Therefore, such immunity is not clear; perhaps at first glance it might appear that this is the current scenario but ultimately mandatory rules of law will apply. Moreover, decisions based on a transnational form of law are not in a vacuum: they are based on accepted general principles of law which can find their origins in different domestic laws.

\footnotetext{
46 Ibid.

47 Ibid.

48 Ibid., p. 3.

49 See for instance the debate about the existence and use of a transnational public policy by arbitrators in Reisman (2007) and Redfern (2007)

50 This is not impossible if the parties in arbitration have an independent contract guarantee in which they will use to pay for the amount established in the award. For a theoretical framework of such possibility see Corte (2012).

51 See Article 54 of the Convention on the Settlement of Investment Disputes Between States and Nationals of Other States that states: 'Article 54 (1) Each Contracting State shall recognise an award rendered pursuant to this Convention as binding and enforce the pecuniary obligations imposed by that award within its territories as if it were a final judgment of a court in that State. A Contracting State with a federal constitution may enforce such an award in or through its federal courts and may provide that such courts shall treat the award as if it were a final judgment of the courts of a constituent state. (2) A party seeking recognition or enforcement in the territories of a Contracting State shall furnish to a competent court or other authority which such State shall have designated for this purpose a copy of the award certified by the Secretary-General. Each Contracting State shall notify the Secretary-General of the designation of the competent court or other authority for this purpose and of any subsequent change in such designation. (3) Execution of the award shall be governed by the laws concerning the execution of judgments in force in the State in whose territories such execution is sought.'
}

CAS, just like any other tribunal, provides its jurisdictional duty once a dispute is brought to its attention. As a result, similar to any other tribunal or court, cause of actions will be repeated leading to reiterated decisions regarding the same subject. Although the CAS case law does not have the same effect as a binding precedent, for reasons of legal certainty and comity, the decisions are being followed. ${ }^{52}$ As a result, CAS 'jurisprudence has notably refined and developed a number of principles of sports law, such as the concepts of strict liability (in doping cases) and fairness, which might be deemed part of an emerging "lex sportiva", ${ }^{53}$ There are other principles of sports law in which it has been deemed to be part of lex sportiva such as 'match decisions are unchallengeable, sporting integrity is maintained', and 'the existence of the "sporting nationality" concept as distinct from the legal definition of nationality'. ${ }^{54}$

The idea of fairness has also been applied in cases that did not refer to the sports competition in itself but the commercial status of the sports entity. In Club Rangers de Talca $v$. Fédération Internationale de Football Association (FIFA), ${ }^{55}$ a dispute arose regarding the payment of a football player while the football club was going through insolvency procedures. Club Ranger, a Chilean football club, was declared bankrupt in 2009 by a Chilean local court. After the decision by the Chilean court, the FIFA dispute resolution chamber determined that Rangers de Talca should pay the amount of USD 21,000 to one of its former football players. As the payment was not made, the footballer asked FIFA to take disciplinary measures against Rangers. In 2010, the assets of Rangers were put on a public auction and Piduco S.A.D.P. acquired the club. As a result, Piduco informed FIFA that it was not liable for the previous debts of the club and it was for the previous bankruptcy receiver to manage the debts and pay them according to Chilean law. Moreover, Piduco stated that it had 'only acquired the federative rights of the relevant club for competing as such in the championships organised by the Chilean National Association of Professional Football', and it had 'not assumed any prior debt corresponding to Club Social y Deportivo Rangers de Talca or any other debt that is not provided for in the document of acquisition of the economic unit'. FIFA maintained the previous decision and Piduco appealed to CAS where it obtained a favourable decision. Under Chilean insolvency law, employees have a privileged credit and get paid first; however, the player failed to join the creditor's list of the bankrupt club when he was aware of such procedure. Therefore, the panel concluded that the player 'somehow contributed not to remove the prerequisite

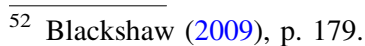

53 Arbitration CAS 2002/O/373 Canadian Olympic Committee (COC) and Beckie Scott/International Olympic Committee (IOC), award of 18 December 2003, para 14.

${ }^{54}$ Parrish (2012), p. 719.

55 Arbitration CAS 2011/A/2646, award of 30 April 2012.
} 
leading to the sanction imposed on the Decision: the lack of payment of the debt ordered in the FIFA DRC decision of 18 June 2009 '.56 Despite the unfavourable decision to the footballer, the panel, when analysing cases of bankruptcy, asserted that the declaration of bankruptcy in different legal systems, stops that bankrupt entity from making payments until there is a decision in the insolvency proceedings. Such a situation creates inequities as all clubs will be playing at the same competition but the clubs in bankruptcy will be under the protection of bankruptcy laws, whereas the other clubs have to make their payments when they are due. CAS followed that '[s]uch inequity of treatment and opportunities is clearly against the essential principles of the so-called "lex sportiva", 57

Another facet of lex sportiva is that it can be used as support to impose a penalty on an athlete or a team. In Andrea Anderson et al v. International Olympic Committee $(I O C),{ }^{58}$ a dispute arose between several athletes from the US Olympic track and field team who competed in the 2000 Sydney Olympic Games and the IOC regarding a doping violation committed by the appellant's teammate in the same Olympic Games. ${ }^{59}$ Because one of the teammates was involved in a doping scandal, the IOC, in 2008, decided to extend the sanction to the rest of the US Olympic track and field team determining that they should retrospectively be disqualified from the competitions held at the 2000 Sydney Olympic Games: $4 \times 100 \mathrm{~m}$ relay, where the team was placed third; and $4 \times 400 \mathrm{~m}$ relay team, where the team was placed first. An appeal was made to CAS against such decision. CAS understood that the sanction could be made but the question it had to decide was 'whether there was on 30 September 2000 an express and clear rule providing that the two relay teams could be disqualified if one of their members committed a doping offence'. ${ }^{60}$ The decision set aside the sanction imposed based on the fact that the penalties applied were supported by rules that were not in force at the time of the alleged offence. The CAS panel stated that the appeal concerned a disciplinary measure and not a doping allegation; hence, they did not address issues of prohibited substances used by the athletes. One of the points raised was that lex sportiva would in principle protect sports from frauds, and as a result, would be able to apply sanctions regardless of the intertemporal effect of the rules imposing such penalties. CAS did not conclude that in this case such circumstance materialised but it did agree that, theoretically, lex sportiva

\footnotetext{
$\overline{56}$ Ibid., para 30.

57 Ibid., para 19(ii).

58 Arbitration CAS 2008/A/1545, award of 16 July 2010.

59 The teammate was Marion Jones who acknowledged using forbidden substances which led to her being disqualified from the competitive event and forfeiture of medals, results and prizes gained.

${ }^{60}$ Arbitration CAS 2011/A/2646, award of 30 April 2012, para 35.
}

could have an established principle allowing the imposition of a sanction. However, for its application, the 'principle must be convincingly demonstrated and must also pass the mentioned predictability test' ${ }^{61}$

Moving from arbitration to courts, the Swiss Federal Tribunal has declared that lex sportiva cannot be recognised as a system of law under PILA. ${ }^{62}$ In a case involving a FIFA agent and a Greek company regarding the transfer of a football player, the court asserted that 'The regulations of a private association cannot be the object of a choice of law according to Art. 116 of the PILA. They can only be incorporated into the contract in accordance with the applicable law, within the limits of the provisions of this law'. ${ }^{63}$ Regarding the lex sportiva, the Swiss Federal Tribunal first declared that regulations from private organisations 'are subordinate to rules that stem from states and can only be applied, where the state rules leave room for autonomous regulation'; after it stated that ' $[\mathrm{t}]$ hey are not "law" in the meaning of Art. 116 (1) PILA and also cannot be accepted as some form of "lex sportiva transnationali", . Finally, it concluded that 'The Rules of the (international) Sports association can only find application through a material reference and thus only be accepted as agreements by the parties'. ${ }^{64}$ Be that as it may, concerning the meaning of the word law in Article 116(1), there is a view that such decision of the Swiss Federal Tribunal about the regulation of sports body did not settle the debate about what law the article is referring to and the Swiss Courts have yet to

\footnotetext{
61 Ibid., para 65.

62 4C.1/2005, Judgment of 20.12.2005.

${ }^{63}$ Ibid., original in French: 'Les règlements d'une association privée ne peuvent pas être l'objet d'une élection de droit selon l'art. 116 LDIP. Ils peuvent seulement être incorporés au contrat conformément au droit applicable, dans les limites des dispositions impératives de ce droit.'

${ }^{64}$ Ibid., the full wording of the original text in German stated: 'Nach der Praxis des Bundesgerichts kommt Regelwerken privater Organisationen auch dann nicht die Qualität von Rechtsnormen zu, wenn sie sehr detailliert und ausführlich sind wie beispielsweise die SIANormen (BGE 126 III 388 E. 9d S. 391 mit Hinweisen) oder die Verhaltensregeln des internationalen Skiverbandes (BGE 122 IV 17 E. 2b/aa S. 20; BGE 106 IV 350 E. 3a S. 352, je mit Hinweisen). Von privaten Verbänden aufgestellte Bestimmungen stehen vielmehr grundsätzlich zu den staatlichen Gesetzen in einem Subordinationsverhältnis und können nur Beachtung finden,so weit das staatliche Recht für eine autonome Regelung Raum lässt (Jérôme Jaquier, La qualification juridique des règles autonomes des organisations sportives, Diss. Neuenburg 2004, Rz. 212). Sie bilden kein 'Recht' im Sinne von Art. 116 Abs. 1 IPRG und können auch nicht als 'lex sportiva transnationalis' anerkannt werden, wie dies von einer Lehrmeinung befürwortet wird (JÉRÔME JAQUIER, a.a.O., Rz. 293 ff.). Die Regeln der (internationalen) Sportverbände können nur im Rahmen einer materiellrechtlichen Verweisung Anwendung finden und daher nur als Parteiabreden anerkannt werden, denen zwingende nationalrechtliche Bestimmungen vorgehen (Keller/Kren Kostkiewicz, Zürcher Kommentar, N. 84 zu Art. 116 IPRG).'
} 
decide if rules of law, such as the UNIDROIT principles, are compatible with Article 116(1). ${ }^{65}$

In another case between an Italian cyclist and the International Cycling Union involving the use by the athlete of prohibited substances, ${ }^{66}$ the Swiss Federal Tribunal acknowledged that there might be a lex sportiva but it did not recognise it. The case started at the domestic level in the Italian Cycling Federation (ICF) and was appealed to CAS, which made a decision banning the athlete from competitions for 2 years beginning on 3 May 2010; it also disqualified the athlete's results as from 7 May 2009 and ordered the payment of a fine of EUR 115,000. The award was challenged at the Swiss Federal Tribunal based on the fact that CAS did not follow procedural rules when it accepted the appeal made by ICF and there was, therefore, a violation of Swiss public policy. The court rejected the challenge and in an obiter dictum, arguing that aspects of sports arbitrations are taken into account by the tribunal such as waiving the right to appeal, it stated that

this does not mean that the same should be done with regard to the general ground of appeal derived from the incompatibility of the award with public policy, unless one would want to create an actual lex sportiva through case law, which could raise some issues from the point of view of the respective competences of the legislature and the judiciary in the Swiss Confederation.

The scope of what is part of lex sportiva is quite wide, and therefore, regardless of the debate about its reality, it is hard to deny that there is an understanding concerning a body of sports principles and rules applied to sports internationally that have been employed to decide sports disputes. This transnational phenomenon is recent to sports law but it is not necessarily a new event. Apart from sports law, there are other areas of law in which equivalent ideas can be found.

\section{The parallel to lex sportiva, the lex mercatoria}

Lex sportiva is not the only source of transnational law. With a similar structure within the area of commercial law the most common source is the lex mercatoria. There are other sources found in scholarly materials, ${ }^{67}$ but for the

\footnotetext{
65 Berger and Kellerhals (2015), pp. 486-487, in footnote 20 where the authors, after showing the view of the Swiss Supreme Court, express: 'But it would appear to us that the Federal Tribunal has not yet made a final determination as to whether, under PILS, Art. 116(1), the parties are at least free to derogate from national law in favour of comprehensive set of rules of law such as, e.g. the Unidroit Principles of International Commercial Contracts.'

66 4A_488/2011, Judgment of 18.06.2012.

67 The literature on the subject might also include other sources such as international and regional instruments, standard terms of contract, restatements of scholars and digest of principles. See Goode et al. (2015), chapter 1 and Cordeiro-Moss (2014), chapter 2.
}

purpose of the present examination lex mercatoria will be employed to trace a parallel with lex sportiva, because the former can be used as the governing law to contracts.

Lex mercatoria dates back to the eleventh century ${ }^{68}$ and developed through the Middle Ages and the Renaissance Period. ${ }^{69}$ Its surge comes from the idea that merchants are the best people to solve their disputes, therefore, the law of merchant was created on the foundation that when merchants have disputes they would solve them based on their own dealings and experiences. Once states and legal systems started to consolidate, laws were imposed on merchants, and as a result, there was a decline on the use of lex mercatoria. ${ }^{70}$ In the second half of the last century, international commerce demanded a transnational approach as the application of domestic law was no longer mirroring the needs of merchants, and sometimes, parties feared the instability found in certain legal systems. ${ }^{71}$ The revival of lex mercatoria had a bigger spectrum as global commerce was faster and more modern. It consisted of ' $[\mathrm{a}]$ set of general principles, and customary rules spontaneously referred to or elaborated in the framework of international trade, without reference to a particular national system of laws', ${ }^{72}$ a truly 'autonomous law of global commerce that fulfils the same functions as the law of the state'. ${ }^{73}$

Paulsson declared that the lex mercatoria has three theoretical conceptions. ${ }^{74}$ The first is that lex mercatoria is, in theory, an autonomous legal system because it is based on a consensus about legal principles that derived from national legal systems. Thus, lex mercatoria is capable of creating rights and imposing obligations only if national legal systems can recognise it. Even so, lex mercatoria would be in an embryonic stage as a legal system. ${ }^{75}$ The second approach is that lex mercatoria is a body of rules susceptible of governing a contract. This is supported by instruments allowing parties to choose rules of law as the governing law to their contract. ${ }^{76}$ The last concept is that lex mercatoria reflects a body of usages and general principles of international commerce. It works by arbitrators applying it in conjunction with a particular domestic law when faced with an issue involving international commerce. This view is not so different from a national judge relying on trade usages to decide a dispute; therefore, lex mercatoria, in a sense, is a way to mature the notion of trade

\footnotetext{
$\overline{68}$ Milgrom et al. (1990), p. 5.

${ }^{69}$ Donahue (2004), p. 23 asserts that the first publication in English about lex mercatoria was made by Gerard Malynes in 1622 titled Consuetudo, vel Lex Mercatoria.

70 Michaels (2007), pp. 454-455.

${ }^{71}$ Lando (1985), p. 748.

72 Mustill (1988), p. 87.

73 Michaels (2007), pp. 454-455.

${ }^{74}$ Paulsson (1990), p. 58.

75 Ibid., p. 65.

${ }^{76}$ Ibid., p. 68.
} 
usages so it can be employed only in international contracts, because the interpretation of such contracts requires a transnational approach. ${ }^{77}$ In Paulsson's opinion, the first and the second concepts are ideals, whereas the third concept has real impact in the practice of arbitration. ${ }^{78}$

As lex mercatoria has been materialised through arbitration, the debate over its true nature is not essential because arbitrators are normally empowered to apply rules of law and not a legal system. ${ }^{79}$ However, when a contract specifies that lex mercatoria or one of its variations is the governing law, defining its content is not an easy task. Lord Mustill drafted a non-exhaustive list of twenty principles. ${ }^{80}$ The contents of the list reflected principles of law that had been accepted in civil and common law jurisdictions to

\author{
$\overline{77}$ Ibid., p. 71. \\ 78 Ibid., p. 60. \\ 79 Pryles (2008), p. 326. \\ ${ }^{80}$ Mustill (1988), pp. 110-114. The list established: '(1) general principle
} that contracts should prima facie be enforced according to their terms: pacta sunt servanda. The emphasis given to this maxim in the literature suggests that it is regarded, not so much as one of the rules of the lex mercatoria, but as the fundamental principle of the entire system; (2) The first general principle is qualified at least in respect of certain long term contracts, by an exception akin to rebus sic stantibus. The interaction of the principle and the exception has yet to be fully worked out; (3) The first general principle may also be subject to the concept of abus de droit, and to a rule that unfair and unconscionable contracts and clauses should not be enforced; (4) There may be a doctrine of culpa in contrahendo; (5) A contract should be performed in good faith; (6) A contract obtained by bribes or other dishonest means is void, or at least unenforceable. So too if the contract creates a fictitious transaction designed to achieve an illegal object; (7) A State entity cannot be permitted to evade the enforcement of its obligations by denying its own capacity to make a binding agreement to arbitrate, or by asserting that the agreement is unenforceable for want of procedural formalities to which the entity is subject; (8) The controlling interest of a group of companies is regarded as contracting on behalf of all members of the group, at least so far as concerns an agreement to arbitrate; (9) If unforeseen difficulties intervene in the performance of a contract, the parties should negotiate in good faith to overcome them, even if the contract contains no revision clause; (10) 'Gold clause' agreements are valid and enforceable. Perhaps in some cases either a gold clause or a 'hardship' revision clause may be implied; (11) One party is entitled to treat itself as discharged from its obligations if the other has committed a breach, but only if the breach is substantial; (12) No party can be allowed by its own act to bring about a non-performance of a condition precedent to its own obligation; (13) A tribunal is not bound by the characterisation of the contract ascribed to it by the parties; (14) Damages for breach of contract are limited to the foreseeable consequences of the breach; (15) A party which has suffered a breach of contract must take reasonable steps to mitigate its loss; (16) Damages for non-delivery are calculated by reference to the market price of the goods and the price at which the buyer has purchased equivalent goods in replacement; (17) A party must act promptly to enforce its rights, on pain of losing them by waiver. This may be an instance of a more general rule, that each party must act in a diligent and practical manner to safeguard its own interests; (18) A debtor may in certain circumstances set off his own cross claims to extinguish or diminish his liability to the creditor; (19) Contracts should be construed according to the principle ut res magis valeat quam pereat; (20) Failure by one party to respond to a letter written to it by the other is regarded as evidence of assent to its terms.' serve as a guidance to apply lex mercatoria. Another list was created by the Centre for Transnational Law of the University of Cologne. Headed by Professor Dr Klaus Peter Berger, the Trans-lex.org website provides a 'systematic online-collection of principles and rules of transnational commercial law, the New Lex Mercatoria'. ${ }^{81}$ There are more than 130 principles that can be used to identify the contents of lex mercatoria. A contrary approach is that the list system is not helpful because lex mercatoria is a transnational rule and it should be analysed as a method. ${ }^{82}$ When faced with a question that requires the application of transnational rules, instead of looking at pre-established principles, it should first be assessed if parties have given directions on how to ascertain the rules and principles. ${ }^{83}$ This can be done by looking at the parties' intentions. If the first step is not achieved, counsel and arbitrators, through comparative law, should try to identify the rule or rules to be applied. ${ }^{84}$ Finally, one has to examine if the identified rule has been accepted as a general principle of law, and therefore, if it can be applied. ${ }^{85}$ Such view implies the use of lex mercatoria by an arbitral tribunal, whereas the previous understanding could be used by a court in a scenario that for some reason the court cannot apply its domestic law. Although there is evidence that lex mercatoria has not always been embraced, ${ }^{86}$ nowadays, owing to the enactment of soft law, it is easier for arbitral tribunals to identify what is the content of lex mercatoria. ${ }^{87}$

${ }_{81}$ In http://trans-lex.org/purpose-concept (accessed on 27 February
2017 ).
${ }^{82}$ Gaillard (1995), p. 224.
${ }^{83}$ Ibid.
${ }^{84}$ Ibid., p. 226.
${ }^{85}$ Gaillard (2001), p. 63.
86 In the International Chamber of Commerce (ICC) interim award 4650 of 1985, arbitrators declined to apply lex mercatoria. The dispute involved a contract between an American and a Saudi Arabian company for construction projects in Jeddah. The agreement had an ICC arbitration clause establishing Geneva as the seat of arbitration and no governing law. The claimant suggested that the applicable law should be either Swiss law or lex mercatoria and the defendant argued that it should be the law of Saudi Arabia or the law of the state of Georgia in the USA. The tribunal understood that for lex mercatoria to be applied such choice would have to be expressed by the parties. 87 The UNIDROIT Principles of International Commercial Contracts, in its preamble, determines that ' $[\mathrm{t}] \mathrm{hey}$ may be applied when the parties have agreed that their contract be governed by general principles of law, the lex mercatoria or the like.' As a result, arbitrators can look at the UNIDROIT principles for guidance in how to apply the lex mercatoria. The same can be said if the dispute involves general rules of contract law in the European Communities as the Principles of European Contract Law also provide in its Article 1:101 that they can be employed if the parties 'have agreed that their contract is to be governed by 'general principles of law', the 'lex mercatoria' or the like'. 
As arbitration rules normally refer to rules of law instead of a legal system, ${ }^{88}$ parties can establish that the applicable law to solve their dispute is the lex mercatoria, although, parties will normally decide on a source of lex mercatoria instead of declaring that the applicable law is lex mercatoria. Be that as it may, it is hard to prove through numerical data that lex mercatoria as a governing law has been a success. In 2005, Drahozal presented empirical data demonstrating that parties in an international contract are not so keen to employ a transnational commercial law. ${ }^{89}$ Looking at International Chamber of Commerce (ICC) data related to arbitration clauses from the years 2000 to 2003, the choice of a nondomestic law reached its peak in 2002 when $2.3 \%$ of the ICC arbitral disputes provided for a transitional law. ${ }^{90}$ His conclusion was that the use of a transnational commercial law will be done 'only if the deterrence benefits from contracting out of national law exceed the likely costs in the form of uncertainty about the governing law rule'. ${ }^{91}$ In 2014, Cuniberti made a quantitative analysis of 8911 ICC cases dating from 1999 to 2012. He demonstrated that less than $2 \%$ of the disputes referred to arbitration had a non-national legal system as a governing law. ${ }^{92}$ Of the contracts that used a non-national law, they referred to the Convention on International Sales of Goods, general principles of law, public international law, principles of equity, the UNIDROIT principles, the INCOTERMS and the law of the European Union. ${ }^{93}$

When there is no express choice of law or the arbitration agreement allows the parties to act as amiable compositeur, there is evidence that arbitrators applied a source of lex mercatoria. In Sapphire International Petroleum Ltd. v. National Iranian Oil Company ${ }^{94}$ the tribunal, applying the conflict of law rules, concluded that Iranian law should apply to solve the dispute. Nevertheless, looking at the intention of the parties and the fact that the contract had no governing law, the tribunal decided that the use of Iranian law was not contemplated by the parties. As a result, the arbitrators determined that general principles of law accepted by civilised nations should be employed to decide

\footnotetext{
88 That is the case for the ICC Arbitration Rules (article 21), the London Chamber of International Arbitration (LCIA) rules (Article 22.3) and the United Nations Commission on International Trade Law Model Law on International Commercial Arbitration (Article 28).

89 Drahozal (2005).

90 Ibid., p 539.

91 Ibid., pp. 536-537.

92 Cuniberti (2014), p. 399

93 Ibid., p. 401.

94 (1963) 35 I.L.R. 136.
}

the dispute. ${ }^{95}$ Similar decisions can be found in institutional arbitration. ${ }^{96}$ Regarding enforcement of arbitral awards, the French Jurisprudence has accepted the application of lex mercatoria. In Societe Fougerolle v. Banque de Proche Orient ${ }^{97}$ the Cour de Cassation ruled that an award based on general principles of obligations applied in international commerce could be enforced because the arbitrators were just doing what they were assigned to do as they were empowered to determine the governing law to solve the dispute. ${ }^{98}$ A similar approach was taken achieved in Compania Valenciana de Cementos Portland SA v. Primary Coal, Inc. ${ }^{99}$ by the Parisian Court of Appeal. The Court understood that the arbitrators, when applying lex mercatoria, conformed to the terms of the submission. ${ }^{100}$ Lex mercatoria reached a stage of recognition in which it

$\overline{95}$ In the ICC Award 3572 of 1982 (1989) YBCA, 111, a dispute related to oil field drilling with no choice of law clause led the arbitrators to decide that 'internationally accepted principles of law' were to be the proper law applicable to the merits of the dispute. See also ICC award 3267 of 1984 (1987) YBCA, 87 in which the arbitrators applied 'generally accepted legal principles governing international commercial relations, without any specific reference to a particular system of law, which was qualified by a learned commentator as a reference to lex mercatoria'.

${ }^{96}$ See, for instance, ICC award no 5721 of 1990 in which the arbitration agreement established that the applicable law was the law of Egypt and the arbitrator could act as amiable compositeur. As a result, the tribunal excluded the application of Egyptian law and decided to make reference to the lex mercatoria by employing the accepted principle of good faith adopted in international trade to solve the dispute. The original version in French of the decision declared: 'L'article 13, paragraphe 5 du Règlement d'arbitrage de la CCI invite le Tribunal à tenir compte des usages du commerce et des textes contractuels. Dans cette perspective, le Tribunal est en droit de se référer à la lex mercatoria. L'autonomie de la clause d'arbitrage, largement reconnue aujourd'hui, justifie cette référence à une règle non étatique déduite des seuls usages du commerce international. En particulier, il se justifie de dissocier le fond du contrat de la validité et la portée de la clause d'arbitrage Ce sera donc en vertu de la notion générale de la bonne foi en affaires, et des usages du commerce international que le Tribunal arbitral se prononcera.'

97 (1982) Rev. Arb. 183.

98 The original version in French declared: 'Mais attendu que l'arrêt relève exactement qu'ense référant aux «principes généraux des obligations généralement applicables dans le commerce international», les arbitresn'ont fait que se conformer à l'obligation qu'ils avaient, en vertu de l'article 8 de l'acte de mission, de définer le droit applicable à l'accord conclu.'

99 (1991) YBCA 142.

100 The arbitrators followed the ICC rules which provided that if no choice of law was made by the parties, the arbitrators could decide the applicable law following the rule of conflict which he deems appropriate, taking into account all cases the provisions of the contract and the trade usages'. As the exercise based on a conflict rule led to either Spanish Law or New York law, which the parties did not intend to be the governing law, the court understood that the arbitrators, when deciding that lex mercatoria would be the applicable law, respected the terms of reference because they were permitted to consider usages of trade. See also Pabalk Ticaret Ltd. Sirketi v. Norsolor SA (1986) YBCA 484. 
can be employed as the contract governing law. It is 'a set of general principles and customary rules spontaneously referred to or elaborated in the framework of international trade, without reference to a particular national system of law, 101

\section{Lex sportiva as the applicable law to sports' contracts}

As described above there are two views of what consists to be the lex sportiva. The first is a narrow view which considers that lex sportiva is made of reiterated decisions in awards issued by CAS; the second, a broader view, states that the concept of lex sportiva does not restrict itself to CAS decisions but it also encompasses SGB regulations. If the SGB regulations are lex sportiva, one could argue that lex sportiva has for a while been the governing law for sports contracts. The only clarification needed to support such a view would be that instead of having a clause in the contract stating that lex sportiva is the governing law, by expressly stating that a specific set of a SGB regulations is the contractual choice of law, the parties would be implying that lex sportiva is the governing law. However, if lex sportiva is made of CAS decisions that are enforcing SGB regulations, the scrutiny is more complex because lex sportiva is not just the SGB regulations but also the CAS decisions on how to interpret such regulations. Moreover, the SGB regulations are not self-sufficient and principles of lex sportiva are also used to complement the regulations when there are gaps in the law. ${ }^{102}$

Party autonomy allows parties to select which law will rule their agreement and in certain scenarios, the law does not have to be a domestic law. Although parties could draft an arbitration clause selecting CAS as the institution to host future arbitral disputes to its contracts, CAS has models of standard clauses to facilitate the procedure. For ordinary arbitral procedures, its clause only specifies that disputes will be 'resolved definitively in accordance with the Code of sports-related arbitration'. ${ }^{103}$ The same sentence can be

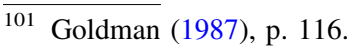

102 Simon (2014), p. 132.

103 In http://www.tas-cas.org/en/arbitration/standard-clauses.html (accessed on 27 February 2017). The full wording of the clause is: 'Any dispute arising from or related to the present contract will be submitted exclusively to the Court of Arbitration for Sport in Lausanne, Switzerland, and resolved definitively in accordance with the Code of sports-related arbitration.'
}

found for submission agreements and for CAS as an appellate body. ${ }^{104}$ The code will comprise the CAS rules and the regulations of the federation, association or sportsrelated body, unlike model clauses found in other arbitral institutions. This suggests that the parties should specify the applicable law, ${ }^{105}$ but CAS does not offer that possibility. Therefore, if parties want to have lex sportiva as their rules of law, perhaps they should draft an arbitration clause based on the standard provided by CAS and include a text stating that the governing law of the contract will be lex sportiva.

Looking at the CAS rules of arbitration, there is room for lex sportiva if that has been chosen by the parties or if the parties have not chosen an applicable law. Under the heading 'Special Provisions Applicable to the Ordinary Arbitration Procedure', rule 45 states that ' $[t]$ he Panel shall decide the dispute according to the rules of law chosen by the parties or, in the absence of such a choice, according to Swiss Law. The parties may authorize the Panel to decide ex aequo et bono'. Just as the practice of other arbitral institutions, a CAS panel can decide according to the rules of law, meaning that it can decide according to a system of law that it is not national. In the absence of a choice, Swiss Law will be applicable, meaning that if the tribunal uses Article 116(1) of PILA, it is unlikely that lex sportiva can be applied. However, if a CAS panel relies on Article 187(1) of PILA, it can decide 'according to the law with which the action is most closely connected' or in equity if the parties authorize it to do so. The decision in equity is similar to the tribunal acting ex aequo et bono, which is provided by CAS rules. Be that as it may, to act ex aequo et bono does not automatically mean you are using lex sportiva, as such conduct allows the arbitrators to act according to the right and good. When it comes to CAS serving as an appellate instance to decisions made by a

\footnotetext{
104 Ibid. For submission agreement: '[Brief description of the dispute] The dispute will be submitted exclusively to the Court of Arbitration for Sport in Lausanne, Switzerland, and settled definitively in accordance with the Code of sports-related arbitration.' For appeals: 'Any decision made by ... [insert the name of the disciplinary tribunal or similar court of the sports federation, association or sports body which constitutes the highest internal tribunal] may be submitted exclusively by way of appeal to the Court of Arbitration for Sport in Lausanne, Switzerland, which will resolve the dispute definitively in accordance with the Code of sports-related arbitration. The time limit for appeal is twenty-one days after the reception of the decision concerning the appeal.'

105 For instance, the LCIA recommended clause has the following text: 'The governing law of the contract shall be the substantive law of []'. In http://www.lcia.org/dispute_resolution_services/lcia_recom mended_clauses.aspx (accessed on 27 February 2017). The same can be said about the Singapore International Arbitration Centre Clause: 'This contract is governed by the laws of ___ In http:// www.siac.org.sg/model-clauses/siac-model-clause (accessed on 27 February 2017).
} 
federation, association or sports-related body, rule 58 asserts that it has to first decide according to the applicable regulations and secondarily, to 'the rules of law chosen by the parties'. If there is no choice-of-law clause, the law where the federation, association or sports-related body is domiciled will apply. Finally, the CAS panel can decide based on the rules of law it 'deems appropriate'. ${ }^{106}$ Through the examination of the CAS regulations, in theory, lex sportiva could be selected by parties as the governing law to their contract; however, if such scenario is presented, two questions can be raised: Why does selecting lex sportiva as the governing law matter in practice? And, how would someone know exactly what the principles, features and rules of lex sportiva are?

\subsection{Why does the choice of lex sportiva selection arise?}

To address the first query, one has to think about the several applicable laws, rules and regulations involving a sport dispute. If the dispute is submitted to CAS, under rule 45 the tribunal will decide according to the rules of law or in the absence of such choice, Swiss Law. Here, if the parties wish to guarantee not only the applications of SGB regulations but also the general accepted principles established by lex sportiva, they would have to express so. Otherwise, the tribunal might not be deciding according to its power as the parties did not consent to the application of lex sportiva. If there is no choice of law, it will depend on the interpretation of Swiss Law, mainly articles 116(1) and 187(1) of PILA. If the latter provision is chosen, rules of law can be applied and therefore lex sportiva can be employed as the governing law. Finally, the tribunal, if the parties authorize, can decide ex aequo et bono and use in this case lex sportiva.

If CAS is working as an appellate body, rule 58 creates a hierarchy of applicable laws. First is the applicable regulation followed by the rules of law. If there is no governing law, the choice is between the domestic law of where the SGB which issued the challenged is domiciled or the rules of law that the tribunal 'deems appropriate'. For instance, if CAS has an appeal from a decision made by a FIFA judicial body, FIFA's regulations will be the first source of law followed by the law chosen by the parties. Hence, if there is a gap in FIFA's regulation and the parties have

\footnotetext{
$\overline{106}$ CAS rules of arbitration, rule 58 declares: 'Law Applicable to the merits. The Panel shall decide the dispute according to the applicable regulations and, subsidiarily, to the rules of law chosen by the parties or, in the absence of such a choice, according to the law of the country in which the federation, association or sports-related body which has issued the challenged decision is domiciled or according to the rules of law the Panel deems appropriate. In the latter case, the Panel shall give reasons for its decision.'
}

chosen lex sportiva as the applicable law, the panel can apply it as the rules of law. Where the governing law is silent, it becomes more complex: if the law where the federation, association or sports-related body is domiciled does not provide for party autonomy or if it does but it only accepts laws originated from countries, the option would be for the tribunal to decide as it deems appropriate and choose to use lex sportiva because it is appropriate.

The question regarding the choice of law raises a problem regarding the concept of lex sportiva. The broader idea could lead to the conclusion that lex sportiva is already the lex contractus. If that is the case, when CAS rule 58 mentions 'regulations' it can be understood that lex sportiva is the lex contractus. But when it refers to rules of law, the SGB regulations are not exactly rules of law. Moreover, the SGB regulations are not sufficient, reason why lex sportiva should be understood as the CAS jurisprudence and the SGBs rules. From that moment, the question of legitimacy is raised as according to the CAS rules, only by an agreement of the parties or when there is no express choice-of-law clause, the CAS tribunal could apply lex sportiva. Hence, expressly stating in a contract that lex sportiva is the governing law would not only respect party autonomy but also legitimise the application of lex sportiva because the tribunal would have clear powers to use it to solve the dispute.

Legitimacy of rules is directly connected to a community, as in the case of lex sportiva, the sports community. For a rule to be legitimate, reference must be made to 'a community's evolving standards of what constitutes right process' ${ }^{107}$ According to Franck, a rule is legitimate when it presents four indicators: 'determinacy, symbolic validation, coherence and adherence'. ${ }^{108}$ The first indicator requires the rule to be clear and transparent so 'one can see through the language of a law to its essential meaning. ${ }^{109}$ By expressing the option for lex sportiva in a contract, it is clear to the parties that it can be applied. The second indicator relates to authorities. A rule that has symbolic validation by showing that authority 'is being exercised in accordance with right process that it is institutionally recognised and validated'. ${ }^{110}$ Once lex sportiva is chosen by the parties, there will be no doubt that the arbitral tribunal was given the power to decide according to it. The third indicator requires that rules "whatever its content, be applied uniformly in every similar and applicable instance'. ${ }^{111}$ For this to happen, the rule depends on the generality of the principles being applied to treat all parties

\footnotetext{
107 Franck (1997), p. 26.

108 Ibid., p. 30

109 Ibid.

110 Ibid., p. 34.

111 Ibid., p. 38
} 
in the same way. Such fairness makes the rule coherent and it precludes 'capricious checkerboarding'. ${ }^{112}$ The lex sportiva in itself tries to bring uniformity to the application and interpretation of international sports laws. Its general principles are employed in a manner used to create a harmonious treatment of sports law in an international sphere. Finally, the adherence indicator makes the connection between a primary rule, which establishes the obligation, and the secondary rules, which govern the execution of the obligation in a community. ${ }^{113}$ Party autonomy will be pictured here as the primary rule as it allows the use of lex sportiva as the governing law. The secondary rule can be the legal system validating CAS, in this case Swiss Law, and the lex sportiva in itself as it is in a way an institutional framework where the sports community has consolidated its principles. Hence, expressly stating in a contract that lex sportiva is the governing law would not only respect party autonomy but also legitimise the application of lex sportiva as the tribunal would have clear powers to use it to solve the dispute.

Be that as it may, the practicality and functionality of choosing lex sportiva as the applicable law raises other arbitral procedural issues. It has been argued that if this were the case, questions of arbitrability of disputes, the law governing the validity of the arbitration agreement and remedies against the award would not be encompassed by lex sportiva. ${ }^{114}$ Moreover, questions regarding mandatory rules of law and public policy such as human rights of athletes and competition law could not be regulated by lex sportiva. ${ }^{115}$ Such view is valid but it is restricted to arbitration, which makes sense because lex sportiva has been applied through CAS arbitration. Although it is a fact that the tentacles of lex sportiva might reach some arbitral procedure issues, the same applies to other types of arbitrations and there are different ways to solve such problems. In effect, specifying that the applicable law is lex sportiva in a sports-related contract would give it more legitimacy and clarity on how CAS rules regarding the applicable law are being interpreted.

\subsection{If you are applying lex sportiva, how do you know its content?}

Once the question of legitimacy is solved, the arbitral tribunal is faced with a second obstacle which is to identify what is the content of lex sportiva? There is no simple answer to this question. In practice, contracts directly related to sports activities involving an athlete will refer to

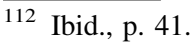

113 Ibid., p. 41.

114 Nafziger (2004), p. 3.

115 Ibid.
}

a SGB regulation and a specific domestic law. For instance, British Swimming, which is 'the national governing body for Swimming, Diving, Synchronised Swimming, Water Polo and Open Water in Great Britain', ${ }^{116}$ has a judicial code that applies to 'all persons (including coaches, trainers and officials) involved in competitions promoted by or on behalf of British Swimming in England, Scotland or Wales'. ${ }^{117}$ This code expresses the rules of the sport for Scotland, England and Wales and it asserts that the laws of England and Wales apply to the code. ${ }^{118}$ If it is a contract to participate in a competition, the athlete will have to agree with the competition's organiser charter and the law imposed in the contract. For instance, the 'Team Membership Agreement - Athletes' made by the Australian Olympic committee for the 2016 Olympic Games, ${ }^{119}$ besides specifying that disputes would be solved by CAS arbitration, ${ }^{120}$ it established that the applicable law would be the law of New South Wales where the agreement was made, and CAS would apply such law. ${ }^{121}$ Similar provision can be found in the Trinidad and Tobago agreement which provides for CAS arbitration but this time without express imposition that CAS has to apply Trinidad's law. ${ }^{122}$ When it comes to commercial transaction deriving from sports activities concluded between an athlete and a private party such as a company that provides sports material, the parties might decide to have lex sportiva as the contractual

\footnotetext{
116 In https://www.britishswimming.org/about-us/ (accessed on 27 February 2017).

117 Section 3.1.1 of the British Swimming 2014 Judicial Code.

118 Ibid., Section 5.1.

119 The model of the agreement can be found in http://aoc-rio2016. s3.amazonaws.com/files/dmfile/ATHLETES\%20-\%202016\%20Aus tralian\%20Olympic\%20Team\%20Membership\%20Agreement $\% 20$ \%20FINAL\%20w\%20Schedules_201015.pdf; (accessed on 27 February 2017).

120 See Clause 18 of the agreement.

121 The clause's wording is: '19 Proper Law 19.1. This Agreement is made in New South Wales and is governed by the laws applicable in the State of New South Wales. 19.2. The Court of Arbitration for Sport will determine any dispute according to the laws applicable to the State of New South Wales. The Seat of the Court of Arbitration for Sport is in Lausanne, Switzerland. 19.3. To the extent that this Agreement is inconsistent with the Code of Sports - Related Arbitration of the Court of Arbitration for Sport, this Agreement prevails and amends the Code to that extent.'

122 Schedule 3 of the Trinidad and Tobago Olympic Committee Team Membership Agreement transposes to the agreement the rules of the Olympic charter which provides for CAS arbitration whilst Clause 20 of the agreement says: '20. Proper Law. 20.1 This agreement is made in Trinidad and Tobago and is governed by the laws applicable in Trinidad and Tobago. 20.2 Should any provision of this agreement or the application thereof be held invalid or unenforceable then the remainder of this agreement and the application thereof will not be affected and will continue valid and enforceable to the fullest extent permitted by law or equity.' In http://www.ttoc.org/index.php/documentation-centre/ttoc-1/7-offi cial-team-membership-agreement (accessed on 27 February 2017).
} 
governing law-but even that is unlikely. Parties will end up selecting a domestic law as it will be better fitted to settle any future dispute. Another scenario could be between companies dealing with business related to sports; but again, it is hard to see how lex sportiva would bring any benefit to the transaction as it is not so easy to identify its content. Moreover, if in this type of scenario parties want to apply a transnational system, lex mercatoria would also be suitable.

Here the parallel with lex mercatoria can be useful. Unlike lex mercatoria, lex sportiva does not have an easy database to access with a list of its principles. Yet, Parrish asserts that through CAS decisions the following new principles were created to settle sports dispute: fair play and the strict liability principle in doping cases, match decisions are unchallengeable; sporting integrity is maintained; teams can be punished for individual infractions; as well as the existence of the 'sporting nationality' concept as distinct from the legal definition of nationality. ${ }^{123} \mathrm{He}$ also declares that the most common principles of law employed by CAS are 'freedom of contract, respect for contracts, force majeure, good faith, protection of legitimate expectations, the contra proferentem principle, equal treatment, proportionality, due process, the right to be heard and the duty to give reasons'. ${ }^{124}$ This list with the common principles of law cannot be understood as lex sportiva because they are general principles of laws found in domestic legislations. Not surprisingly, they can also be considered established principles of lex mercatoria.

It is reasonable that CAS through its reiterated decisions will create an understanding of how to approach questions of sports law; hence, '[a]n obvious purpose for developing a lex sportiva is to guide later awards, and thereby stabilize expectations about arbitration of particular issues'. ${ }^{125}$ The function of lex sportiva as a supplement to help filling the gaps of the regulations of sport bodies or the applicable state law guiding sports arbitration should be welcomed but lex sportiva as the governing law of a contract still raises uncertainty. The lex mercatoria in itself causes confusion and although there are instruments such as the UNIDROIT Principles of International Commercial Contracts and the Principles of European Contract Law that can be used as lex mercatoria, they are not exactly lex mercatoria. Some of its principles might be based on ideas considered to be lex mercatoria, but in reality, they serve as a substitute for it. Perhaps, it would be different if CAS developed something akin to the mentioned soft laws, which would clarify what exactly comprises the content of lex sportiva.

Conceivably, a better manner to employ lex sportiva is to follow the second approach set for lex mercatoria, that

\footnotetext{
123 Parrish (2012), p. 718.

124 Ibid., pp. 718-719.

125 Nafziger (2004), p. 3.
}

is, to apply it as a method. Hence, one must look at the parties' intention and assess if the parties established how lex sportiva can be used. The second step, looking at comparative law, might not be as easy as in commercial disputes. Nevertheless, there are plenty of regulations regarding sports law from different jurisdictions that can serve as a source for the second phase of the method approach. The last step, analysing if the principles being enforced are accepted as general principles of law, can easily be done just by looking at the CAS case law. The method approach would provide an exercise with a process that not only legitimises the intention of the parties but it also identifies the content of lex sportiva.

Knowing the content of lex sportiva becomes paramount for its acceptance as a contractual governing law. It is not often that parties will choose a transnational system as the governing law as it can bring uncertainty. In arbitration, the parties are free to choose the law or rules of law that will be applicable to decide the dispute; but in courts, party autonomy does not thrive in the same manner. Even when parties have decided to rely on principles of a domestic system this can cause problems. In Channel Group v. Balfour Beatty Ltd $^{126}$ a dispute arose in relation to the construction of the Eurotunnel. The parties diverged in relation to the amount due for the tunnel's cooling system. A request to stay the arbitration was made and rejected by English courts. The contract had an arbitration clause and a choice-of-law clause stating that the contract would be governed by 'principles common to both English law and French law'. ${ }^{127}$ It is clear that although similarities can be found in both legal systems, it is hard to set principles common to English and French law that could be applied. $^{128}$

In commercial transactions in the field of sports, the use of lex sportiva does not seem functional. Examining the principles presented above that are recognised as lex

\footnotetext{
126 [1993] A.C. 334.

127 Ibid., the full wording of the clause was: 'The construction, validity and performance of the contract shall in all respects be governed by and interpreted in accordance with the principles common to both English law and French law, and in the absence of such common principles by such general principles of international trade law as have been applied by national and international tribunals. Subject in all cases, with respect to the works to be respectively performed in the French and in the English part of the site, to the respective French or English public policy (ordre public) provisions.'

${ }^{128}$ For instance, if the object of a dispute submitted to arbitration relates to formation of contracts, it would be hard for a common ground to be reached. In English and Welsh law for a contract to be formed it is essential for it to have consideration which is an element of contract formation that does not exist in French law. A similar scenario can be presented if the principle of contractual good faith is raised. In French Law, the contractual parties are under an implied duty to act in good faith whereas in English and Welsh law they are not.
} 
sportiva, it seems that most of them are directly related to sports activities such as agreements for athletes to be in a competition or a club being part of a competition. Hence, the ideas behind lex sportiva are not an attractive source of law for commercial contracts involving sports activities. Nevertheless, for contracts related directly to sports activities, lex sportiva has its merits. As CAS is the stage for lex sportiva and its disputes concern international sports law, having a harmonious approach to decision making brings stability to the sports arena. As a result, in such cases, despite the volatility in relation to the content of lex sportiva, through the method system and having only one venue deciding international sports disputes, the uncertainty becomes secondary and lex sportiva as the contractual governing law does not seem so theoretical.

\section{Conclusion}

The present study set out to verify the possibility of lex sportiva being the choice of law in a contract. Lex sportiva has developed through the reiterated decisions of CAS, forming a source of transnational law. In this aspect, lex sportiva finds similarities to lex mercatoria as they are both sources of transnational law and they thrive through arbitration. So far, lex sportiva has been applied by CAS when deciding international sports disputes. Examining the rules applicable to sports and other instruments, whether national or international, it can be concluded that party autonomy would make no obstacles for lex sportiva to be the contractual governing law. The problems faced by such choice can generate uncertainty. First would be what is lex sportiva? The definition of lex sportiva does not find a unanimous approach and hence, it would be for the adjudicator to decipher what is lex sportiva before a decision can be made. The second hurdle is the legitimacy in its application. Unless it is clear that the parties wanted lex sportiva to be the governing law—or the rules of law of the contract—applying it without the parties' authority under CAS rules might indicate that a decision has been made outside the scope of the arbitration agreement. Finally, the content of lex sportiva can be hard to identify, although through the method system such a barrier can easily be given a solution. Lex sportiva might need more time to reach a stage of clarity; and for now, it might be better for CAS to continue developing it before it becomes a common contractual choice of law.

Open Access This article is distributed under the terms of the Creative Commons Attribution 4.0 International License (http://crea tivecommons.org/licenses/by/4.0/), which permits unrestricted use, distribution, and reproduction in any medium, provided you give appropriate credit to the original author(s) and the source, provide a link to the Creative Commons license, and indicate if changes were made.

\section{References}

Anderson J (2010) Modern sports law, a textbook. Hart, Oxford

Beloff M, Kerr T, Demetriou M, Beloff R (2012) Sports law, 2nd edn. Hart, Oxford

Berger B, Kellerhals F (2015) International and domestic arbitration in Switzerland, 3rd edn. Hart, Oxford

Blackshaw I (2009) Sport, mediation and arbitration. TMC Asser Press, Lausanne

Blackshaw I (2011) Towards a 'lex sportiva'. Int Sports Law J $1-2: 140-144$

Casini L (2011) The making of a lex sportiva by the court of arbitration for sport. Ger Law J 12(5):1317-1340

Cordeiro-Moss G (2014) International commercial contracts. Cambridge University Press, Cambridge

Corte CG (2012) Lex mercatoria, international arbitration and independent guarantees: transnational law and how nation states lost the monopoly of legitimate enforcement. Transnatl Leg Theory 3(4):345-370

Cuniberti G (2014) Three theories of lex mercatoria. Columbia J Transnatl Law 52(2):369-434

Davis T (2001) What is sports law? Marquette Sports Law Rev 11(2):211-244

Donahue C Jr (2004) Medieval and early modern lex mercatoria: an attempt at the probatio diabolica. Chic J Int Law 5(1):21-37

Drahozal CR (2005) Contracting out of national law: an empirical look at the new law merchant. Notre Dame Law Rev 80(2):523-552

Duval A (2013) Lex sportiva: a playground for transnational law. Eur Law J 19(6):822-842

Foster K (2003) Is there a global sports law? Entertain Law 2(1):1-18

Franck TM (1997) Fairness in international law and institutions. Oxford University Press, Oxford

Gaillard E (1995) Thirty years of lex mercatoria: towards the selective application of transnational rules. ICSID Rev 10(2):208-231

Gaillard E (2001) Transnational law: a legal system or a method of decision making? Arbitr Int 17(1):59-72

Gardiner S, O’Leary J, Welch R, Boyes S, Naidoo U (2006) Sports law. Routledge, London

Goldman B (1987) The applicable law: general principles of law-the lex mercatoria. In: Lew JDM (ed) Contemporary problems in international arbitration. Martinus Nijhoff, Dordrecht

Goode R, Kronke H, Mckendrick E (2015) Transnational commercial law, text, cases and materials, 2nd edn. Oxford University Press, Oxford

Graziano TK (2009) Comparative contract law, cases material and exercises. Palgrave MacMillan, Basingstoke

Kolev B (2008) Lex sportiva and lex mercatoria. Int Sports Law J $1-2: 57-62$

Lando O (1985) The lex mercatoria in international commercial arbitration. Int Comp Law Q 34(4):747-768

Latty F (2007) La lex sportiva: recherche sur le droit transnational. Brill Academic, Leiden

McLaren RH (2001) The court of arbitration for sport: an independent arena for the world's sports disputes. Valpso Univ Law Rev 35(2):379-405

Michaels R (2007) The true lex mercatoria: law beyond the state. Indiana J Glob Leg Stud 14(2):447-468

Milgrom PR, North DC, Weingast BR (1990) The role of institutions in the revival of trade: the law merchant, private judges, and the champagne fairs. Econ Politics 2(1):1-23

Mustill M (1988) The new lex mercatoria: the first twenty-five years. Arbitr Int 4(2):86-119

Nafziger JAR (2004) Lex sportiva. Int Sports Law J 1-2:3-8 
Panagiotopoulos DP (2011) Lex sportiva and international legitimacy governing: protection of professional players. US China Law Rev 8(2):121-136

Parrish R (2012) Lex sportiva and EU sports law. Eur Law Rev 37(6):716-733

Paulsson J (1990) La lex Mercatoria dans l'arbitrage CCI. Revue de l'Arbitrage 1 Janvier-Mars:55-100

Petsche M (2014) The application of transnational law (lex mercatoria) by domestic courts. J Priv Int Law 10(3):489-515

Pryles M (2008) Application of the lex mercatoria in international commercial arbitration. UNSW Law J 31(1):319-329

Redfern A (2007) Comments on commercial arbitration and transnational public policy. In: Van Der Berg A (ed) International arbitration 2006: back to basics?, vol 13. ICCA Congress series, 2006. Kluwer Law International, Montreal

Reisman MW (2007) Law, international public policy (so-called) and arbitral choice in international commercial arbitration. In: Van Der Berg A (ed) International arbitration 2006: back to basics?, vol 13. ICCA Congress series, 2006. Kluwer Law International, Montreal

Siekmann RCR (2011) What is sports law? Lex sportiva and lex ludica: a reassessment of content and terminology. Int Sports Law J 1-2:3-15

Simon G (2014) Arbitrage et ordre public sportif. In: Loquin E, Manciaux S (eds) L'ordre public et l'arbitrage. Lexis Nexis, Paris

Teubner G (1997) Global Bukowina: legal pluralism in the world society. In: Teubner G (ed) Global law without a state. Dartmouth Publishing, Aldershot

Wolf KD (2014) The non-existence of private self-regulation in the transnational sphere and its implications for the responsibility to procure legitimacy: The case of the lex sportiva. Glob Const 3(3):275-309

Zhang M (2006) Party autonomy and beyond: an international perspective of contractual choice of law. Emory Int Law Rev 20:511-562 